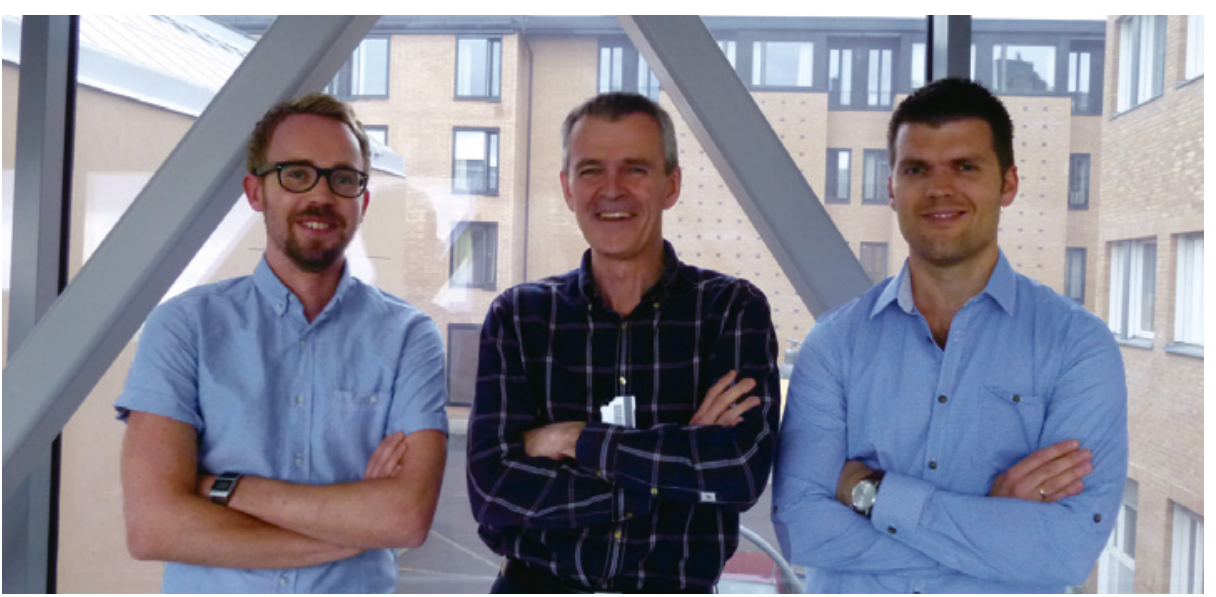

Tre av deltakerne i forskergruppen og medforfattere av artiklene. Fra venstre Olav Sundnes, Guttorm Haraldsen og Eirik Sundlisæter. Foto Anne Marthe Fosdahl
Ordforklaringer

Alarmin: Et endogent molekyl som aktiverer immunsystemet ved å signalisere skade av celler og vev.

Interleukin: Fellesbetegnelse på løselige proteiner som formidler signaler mellom ulike typer celler, blant annet under inflammasjonsresponsen.

Endotel: Enkelt cellelag som kler innsiden av blodkar og lymfekar.

\title{
Regulering av inflammasjon i karendotel
}

\author{
Norske forskere har funnet en sammenheng mellom signalsystemet
}

Notch og inflammasjon i karendotel.

Signalsystemet Notch ble første gang beskrevet for nesten 100 år siden. Thomas Hunt Morgan, en amerikansk genetiker, identifiserte da en mutert stamme av bananfluen (Drosophila) med hakk (notch) i vingene. Senere viste det seg at denne signalveien kontrollerer celledeling og cellemodning hos alle flercellede dyr og er sentral for utvikling av hjerte- og karsystemet.

I en artikkel som nylig er publisert i tidsskriftet American Journal of Pathology har forskere ved Universitetet i Oslo vist at Notch-signalsystemet regulerer uttrykket av alarminet interleukin-33 (IL-33) i endotelceller (1). Alarminer er endogene molekyler som vanligvis ikke er synlige for immunsystemet, men blir synlige ved vevsskade. Endotelceller som ikke er i aktiv cellesyklus har et høyt ekspresjonsnivå av IL-33, mens ekspresjon nedreguleres ved nydanning av kar. Ved vevsskade frigjøres IL-33 fra endotelceller.

Forskerne har i en annen artikkel vist at interleukin-33 også aktiverer andre endotelceller (2) og har en viktig rolle i flere inflammatoriske tilstander, bl.a. astma og atopisk eksem.

- Disse studiene åpner opp et helt nytt område innen biologien som Notch tidligere ikke har vært involvert $i$, nemlig reguleringen av inflammasjonsresponsen i karendotel, sier lege og forsker Eirik Sundlisæter, som er en av forskerne bak artiklene. Det kan se ut som Notch er en viktig modulator for aktivering og regulering av endotelceller ved inflammasjon. Vi arbeider nå videre med dette i flere nye prosjekter. Man kan ikke se bort fra at molekyler i dette signalsystemet kan bli et mål for nye antiinflammatoriske legemidler, sier Sundlisæter.

\section{Forskergruppen}

Forskergruppen Inflammasjon og vaskulcer biologi ved Avdeling for patologi, Oslo universitetssykehus og Det medisinske fakultet ved Universitetet i Oslo, er en del av det nyopprettede K.G. Jebsen-senter for betennelsesforskning. Forskergruppen fokuserer på å forstå endotelfunksjon og samspill med leukocytter og stromale celler under normale forhold og ved sykdom.

Gruppen ledes av Guttorm Haraldsen og består ellers av professor Helge Scott, Reidunn Jetne Edelmann, Nadine Frerker, Johanna Hol, Monika Kasprzycka, Clara Louise Hammarström, Denis Khnykin, Stig Krüger, Eirik Sundlisæter og Olav Sundnes. Hovedmålet er å drive basalfaglig og translasjonell forskning på høyt internasjonalt nivå og frembringe kunnskap som leder til nye behandlingsmuligheter for pasienter.

Forskergruppen samarbeider med en rekke institusjoner i inn- og utland, bl.a. Max Planck-instituttet i Münster, Universitetet i Wien, Universitetet i Oxford og Universitetet i Helsinki. Gruppen er en del av Inflammatory Research Net (IRNet), som er nettverk finansiert av Helse Sør-Øst og med mål om å fremme translasjon av basal inflammasjonsforskning til klinisk praksis.

\section{Hanne Støre Valeur}

hanne.store.valeur@legeforeningen.no

Tidsskriftet

\section{Litteratur}

1. Sundlisaeter E, Edelmann RJ, Hol J et al. The alar min IL-33 is a notch target in quiescent endothelial cells. Am J Pathol 2012; 181: 1099-111.

2. Pollheimer J, Bodin J, Sundnes 0 et al. Interleukin-33 drives a proinflammatory endothelial activation that selectively targets nonquiescent cells. Arterioscler Thromb Vasc Biol 2013; 33: e47-55.
The American Journal of PATHOLOGY

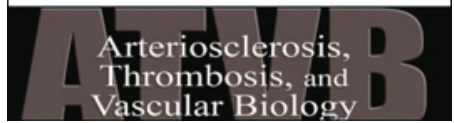

Artiklene er publisert i tidsskriftene American Journal of Pathology og Arteriosclerosis, Thrombosis, and Vascular Biology 